\title{
Towards Enhanced MRI Performance of Tumor-Specific Dimeric Phenylboronic Contrast Agents
}

\author{
Jonathan Martinelli ${ }^{1,2}{ }^{\oplus}$, Lorenzo Tei $^{2} \oplus$, Simonetta Geninatti Crich ${ }^{3}\left(\mathbb{D}\right.$, Diego Alberti ${ }^{3}$ and \\ Kristina Djanashvili ${ }^{1, *(\mathbb{D})}$ \\ 1 Department of Biotechnology, Delft University of Technology, Van der Maasweg 9, \\ 2629 HZ Delft, The Netherlands; jonathan.martinelli@uniupo.it \\ 2 Department of Science and Technological Innovation, Università del Piemonte Orientale, Viale Michel 11, \\ 15121 Alessandria, Italy; lorenzo.tei@uniupo.it \\ 3 Department of Molecular Biotechnology and Health Sciences, University of Torino, Via Nizza 52, \\ 10126 Torino, Italy; simonetta.geninatti@unito.it (S.G.C.); diego.alberti@unito.it (D.A.) \\ * Correspondence: k.djanashvili@tudelft.nl; Tel.: +31-15-278-9052
}

Citation: Martinelli, J.; Tei, L.; Geninatti Crich, S.; Alberti, D.;

Djanashvili, K. Towards Enhanced MRI Performance of Tumor-Specific Dimeric Phenylboronic Contrast Agents. Molecules 2021, 26, 1730. https://doi.org/10.3390/ molecules 26061730

Academic Editor: Laurent Chabaud

Received: 21 February 2021

Accepted: 16 March 2021

Published: 19 March 2021

Publisher's Note: MDPI stays neutral with regard to jurisdictional claims in published maps and institutional affiliations.

Copyright: (C) 2021 by the authors Licensee MDPI, Basel, Switzerland. This article is an open access article distributed under the terms and conditions of the Creative Commons Attribution (CC BY) license (https:/ / creativecommons.org/licenses/by/ $4.0 /)$.

\begin{abstract}
It is known that phenylboronic acid (PBA) can target tumor tissues by binding to sialic acid, a substrate overexpressed by cancer cells. This capability has previously been explored in the design of targeting diagnostic probes such as Gd- and ${ }^{68} \mathrm{Ga}-\mathrm{DOTA}-\mathrm{EN}-\mathrm{PBA}$, two contrast agents for magnetic resonance imaging (MRI) and positron emission tomography (PET), respectively, whose potential has already been demonstrated through in vivo experiments. In addition to its high resolution, the intrinsic low sensitivity of MRI stimulates the search for more effective contrast agents, which, in the case of small-molecular probes, basically narrows down to either increased tumbling time of the entire molecule or elevated local concentration of the paramagnetic ions, both strategies resulting in enhanced relaxivity, and consequently, a higher MRI contrast. The latter strategy can be achieved by the design of multimeric $\mathrm{Gd}^{\mathrm{III}}$ complexes. Based on the monomeric PBA-containing probes described recently, herein, we report the synthesis and characterization of the dimeric analogues $\left(\mathrm{Gd}^{\mathrm{III}} \text {-DOTA-EN }\right)_{2}$-PBA and (Gd ${ }^{\mathrm{III}}$-DOTA-EN $)_{2} \mathrm{~F}_{2}$ PBA. The presence of two Gd ions in one molecule clearly contributes to the improved biological performance, as demonstrated by the relaxometric study and cell-binding investigations.
\end{abstract}

Keywords: gadolinium complexes; MRI contrast enhancement; phenylboronic acid; sialic acid; tumor targeting

\section{Introduction}

Boronic acids continue to find wider applications in biomedical research, material science, chemical synthesis and electronics [1]. In particular, the recent interest in phenylboronic acid (PBA) for diagnostic and therapeutical purposes has arisen from its ability to bind sialic acid (SA), a nine-carbon monosaccharide unit that is overexpressed as the terminal group of glycolipids and glycoproteins on the surface of tumor cells [2], thus making them exploitable in the design of targeting contrast agents. PBA derivatives can reversibly form five- or six-membered cyclic boronate esters with the exocyclic polyol chain of SA [3], and this property has already been exploited in the preparation of a few diagnostic targeting probes [4-6]. Among them, Gd ${ }^{\mathrm{III}}$-DOTA-EN-PBA has proven particularly successful as a magnetic resonance imaging (MRI) contrast agent for in vivo tumor targeting based on the recognition of overexpressed sialic acid [7]. This Gd ${ }^{\mathrm{III}}$ complex bears a PBA group conjugated to a polyamino-polycarboxylic ligand for paramagnetic ions (DOTA $=1,4,7,10$-tetraazacyclododecane-1,4,7,10-tetraacetic acid) through an aminoethylamide spacer (EN = ethylenediamine) (Figure 1). It was proven that a two-site cooperative binding mechanism takes place: on one side, the previously mentioned formation of a cyclic boronate between the $\mathrm{B}(\mathrm{OH})_{2}$ moiety and the diol of the substrate; on the other side, 
recognition is enhanced by an electrostatic interaction between the negatively charged carboxylate on the SA residue and the positively charged amine of the linker between the macrocycle and PBA. The success of Gd ${ }^{\mathrm{III}}$-DOTA-EN-PBA targeting led to further investigation of this ligand with the radioactive ${ }^{68} \mathrm{Ga}{ }^{I I I}$ ion, enabling visualization of tumors by positron emission tomography (PET) [8]. Very recently, a paper was published by our group reporting a double improvement regarding this type of functionalized ligand: a more efficient synthetic procedure and an enhancement in binding capability [9]. Concerning the former issue, it is well-known that the amphiphilic character of boronates causes difficulties in their preparation and purification, including solubility problems, tendency to form oligomers or react with nucleophilic species, and the $\mathrm{pH}$ dependence of the equilibrium between a boronic acid and its boronate [10]. In our synthetic approach, we exploited solid-phase synthesis to overcome all these problems by binding the boronic site to a suitable functionalized support (DEAM-PS resin) [11-13] for temporary protection of the moiety, thus obtaining a final cleaner product at a higher yield [9]. This procedure was then successfully applied to prepare an analogous ligand modified at the phenyl ring with the introduction of two electron-withdrawing fluorine atoms in order to increase the acidity of the phenylboronic group and, consequently, its ability to bind SA residues on the surface of tumor cells. The switch of the boronate from the meta-position in DOTA-EN-PBA to the para-position in the novel DOTA-EN- $\mathrm{F}_{2} \mathrm{PBA}$ allowed testing of the importance of the formation of the cyclic boronate in the recognition mechanism, regardless of the additional contribution of the previously mentioned amine-carboxylate electrostatic interaction. The cell binding experiments that were carried out with the Gd ${ }^{\mathrm{III}}-\mathrm{DOTA}-\mathrm{EN}-\mathrm{F}_{2} \mathrm{PBA}$ complex confirmed the improved affinity that counterbalanced the loss of the electrostatic effect.

Herein, we report a further advancement in the DOTA-EN-PBA-based ligands consisting of their dimeric analogues (DOTA-EN) $)_{2}-\mathrm{PBA}$ and (DOTA-EN) $)_{2}-\mathrm{F}_{2} \mathrm{PBA}$ (Figure 1). Due to the intrinsic low sensitivity of MRI, the preparation of dimers or multimers (e.g., tetramers, hexamers, etc.) has become a common strategy to improve the performance of MRI contrast agents by increasing the local concentration of paramagnetic ions and the global tumbling time $\left(\tau_{R}\right)$ of the agent. A high relaxivity density (i.e., high relaxivity per Gd ion) usually implies a significant enhancement of the relaxation rate per mass unit of MRI agent, often referred to as mass relaxivity [14], which represents an important parameter in molecular imaging applications. On the other hand, an increased molecular size leads to a lengthening in $\tau_{\mathrm{R}}$ and, in turn, a higher longitudinal relaxivity $r_{1}$. Examples of ditopic DOTA-like systems were reported by using $\mathrm{Gd}^{\mathrm{III}}$-DOTA monoamide [15,16],

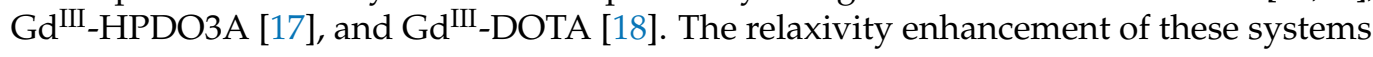
as compared to monomeric Gd complexes was often very much dependent on the water exchange rate or on the rigidity of the linker. The two novel ligands reported in the present work, still prepared by exploiting the proven advantages of solid-phase synthesis, are endowed with two DOTA-macrocycles connected via EN-linkers to a phenylboronic acid or a difluorophenylboronic acid, respectively. The two resulting DOTA monoamide (DOTAMA) macrocycles in each ligand are well known to form thermodynamically and kinetically stable chelates with $\mathrm{Gd}^{\mathrm{III}}$ ions [19].

For consistency in the comparison, the positions of the boronic acid moiety and the fluorine atoms with respect to the aromatic ring were maintained exactly the same as in the monomeric ligands. The corresponding $\mathrm{Gd}^{\mathrm{III}}$ complexes of both chelates were then prepared and fully characterized through standard ${ }^{1} \mathrm{H}$ and ${ }^{17} \mathrm{O}$ NMR relaxometric techniques. Finally, the targeting abilities and contrast enhancement of the novel dimeric $\left(\mathrm{Gd}^{\mathrm{III}} \text {-DOTA-EN }\right)_{2}-\mathrm{F}_{2} \mathrm{PBA}$ complex were investigated on suitable tumor cell cultures, i.e., cell cultures overexpressing a sufficient amount of SA. 


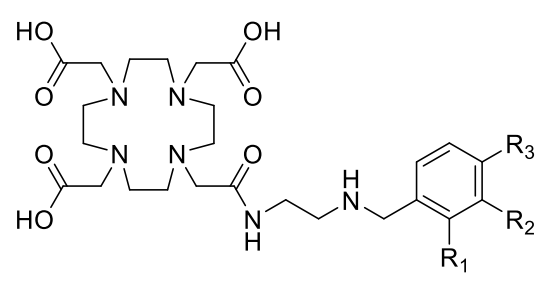

DOTA-EN-PBA: $\mathrm{R}_{1}=\mathrm{R}_{3}=\mathrm{H}, \mathrm{R}_{2}=\mathrm{B}(\mathrm{OH})_{2}$ DOTA-EN-F ${ }_{2}$ PBA: $\mathrm{R}_{1}=\mathrm{R}_{2}=\mathrm{F}, \mathrm{R}_{3}=\mathrm{B}(\mathrm{OH})_{2}$<smiles>[R]c1ccc(CNC(CNC(=O)CN2CCN(CC(=O)O)CCN(CC(=O)O)CCN(CC(=O)O)CC2)CNC(=O)CN2CCN(CC(=O)O)CCN(CC(=O)O)CCN(CC(=O)O)CC2)c([R])c1[R]</smiles>

(DOTA-EN) ${ }_{2}$-PBA: $\mathrm{R}_{1}=\mathrm{R}_{3}=\mathrm{H}, \mathrm{R}_{2}=\mathrm{B}(\mathrm{OH})_{2}$

(DOTA-EN) ${ }_{2}-\mathrm{F}_{2}$ PBA: $\mathrm{R}_{1}=\mathrm{R}_{2}=\mathrm{F}, \mathrm{R}_{3}=\mathrm{B}(\mathrm{OH})_{2}$

Figure 1. Structures of monomeric (DOTA-EN)- and dimeric (DOTA-EN) $)_{2}$-phenylboronic compounds.

\section{Results and Discussion}

\subsection{Synthesis}

The first part of the synthesis of the (DOTA-EN) ${ }_{2}$-ligands (Scheme 1) started with the preparation of $N, N^{\prime}$-di-Boc-2-azido-1,3-diaminopropane 1 (Boc = tert-butoxycarbonyl protecting group) according to a reported procedure [20]. The amino groups of 1,3-diamino2-propanol were protected with di-tert-butyl dicarbonate and then the hydroxyl group was activated as the corresponding mesylate and converted into an azide.

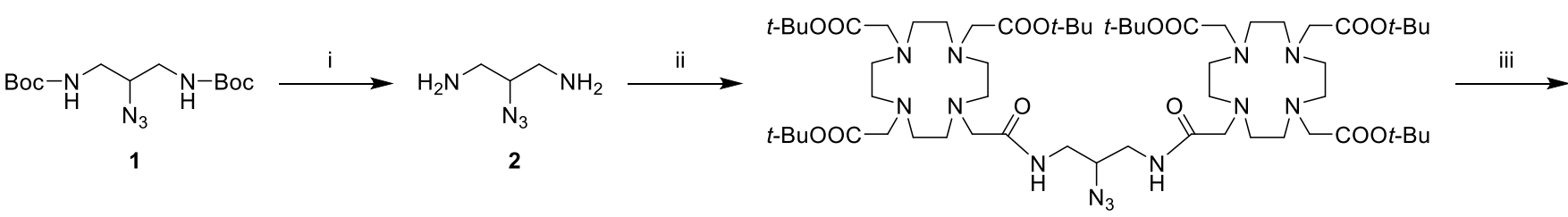

3
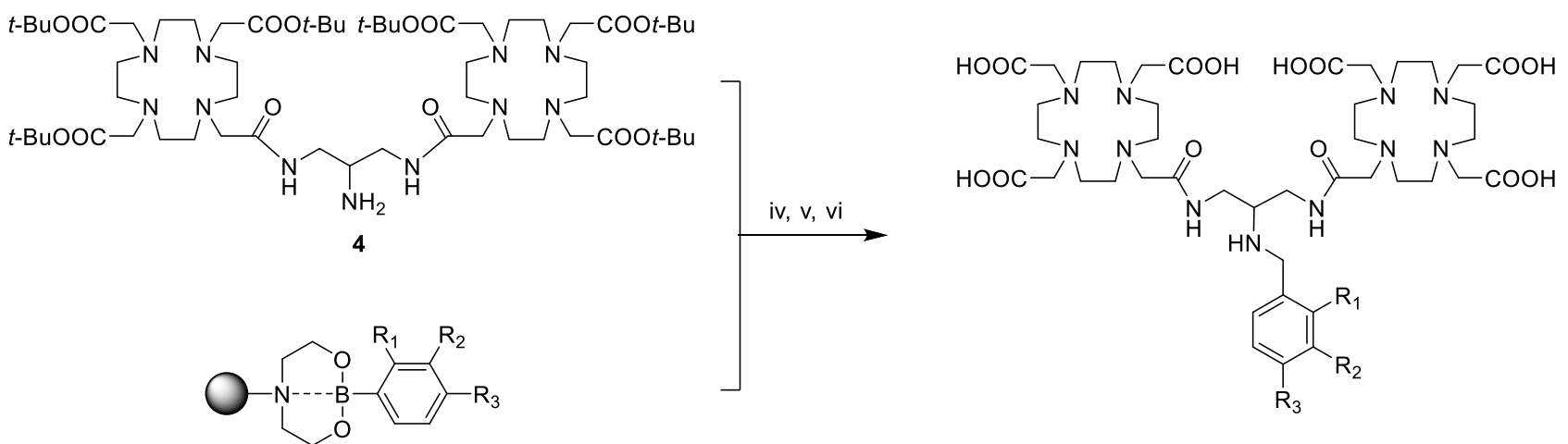

$\operatorname{Resin} A: R_{1}=R_{3}=H, R_{2}=C H O$

(DOTA-EN) ${ }_{2}$-PBA: $\mathrm{R}_{1}=\mathrm{R}_{3}=\mathrm{H}, \mathrm{R}_{2}=\mathrm{B}(\mathrm{OH})_{2}$

Resin $B: R_{1}=R_{2}=F, R_{3}=C H O$

(DOTA-EN) ${ }_{2}-F_{2}$ PBA: $R_{1}=R_{2}=F, R_{3}=B(O H)_{2}$

Scheme 1. Synthesis of (DOTA-EN) $)_{2}$-PBA and (DOTA-EN) $)_{2}-\mathrm{F}_{2}$ PBA: (i) $4 \mathrm{M} \mathrm{HCl}$, dioxane, rt, 15 h; (ii) DOTA(Ot-Bu) HBTU, HOBt, DIPEA, DMF, rt, 15 h; (iii) $\mathrm{H}_{2}$, Pd/C, rt, 3 h; (iv) THF, rt, 3 h; (v) NaBH , THF, rt, 4 h; (vi) TFA, DCM, rt, 1 h.

The two primary amines of $\mathbf{1}$ were deprotected by stirring the compound in $4 \mathrm{M} \mathrm{HCl}$, leading to compound $\mathbf{2}$ as hydrochloride salt that was reacted directly with tris-tert-butylprotected DOTA in the presence of peptide coupling agents to obtain the dimer 3 . The DOTA-precursor was, in turn, prepared converting commercial DO3A hydrobromide salt into its monoethyl ester [7] that was hydrolyzed under strong alkaline conditions into the corresponding carboxylic acid. The azide moiety of $\mathbf{3}$ was then reduced to amine, leading to the product 4 , which was used in a reductive amination with the suitable 
formylphenylboronic acid previously immobilized on DEAM-PS resin. Final cleavage and deprotection with TFA afforded the desired compounds. The characterization of the intermediates and the final products was performed via IR and NMR spectroscopies (Figures S1-S3). (DOTA-EN) $)_{2}-\mathrm{PBA}$ and (DOTA-EN) $)_{2}-\mathrm{F}_{2} \mathrm{PBA}$ were obtained with a final 32 and $36 \%$ yield, respectively, and the part of the process involving a boronate moiety was easily carried out thanks to the previously mentioned advantages of solid-phase synthesis. Such results confirm the validity of the synthetic protocol recently reported by our group for the preparation of this type of functionalized ligand [9].

The corresponding Gd ${ }^{\mathrm{III}}$ complexes $\left(\mathrm{Gd}^{\mathrm{III}} \text {-DOTA-EN)}\right)_{2}$-PBA and $\left(\mathrm{Gd}^{\mathrm{III}} \text {-DOTA-EN) }\right)_{2}$ $\mathrm{F}_{2}$ PBA were prepared by mixing each ligand with a slight excess of $\mathrm{GdCl}_{3}$ hexahydrate (Scheme 2). The unreacted $\mathrm{Gd}^{\mathrm{III}}$ was precipitated as hydroxide at $\mathrm{pH} 10$ and filtered off. The formation of the complexes was confirmed by ESI ${ }^{+}$mass spectrometry (Figures S4 and S5). The paramagnetic complexes obtained upon lyophilization were used directly to investigate their properties in terms of performance as MRI contrast agents and targeting probes. The stability of the novel probes can be considered similar to the monomeric analogue Gd-DOTA-EN-PBA such as it has been found in transmetallation studies with endogenous $\mathrm{Zn}^{\mathrm{II}}$ ions in the presence of phosphate buffer (Figure S6) [21].

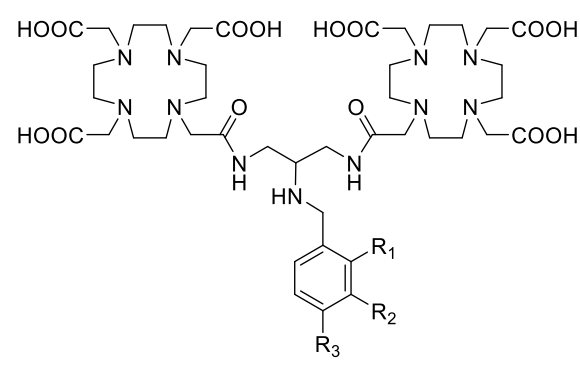

(DOTA-EN) $)_{2}$-PBA: $\mathrm{R}_{1}=\mathrm{R}_{3}=\mathrm{H}, \mathrm{R}_{2}=\mathrm{B}(\mathrm{OH})_{2}$

(DOTA-EN) ${ }_{2}-\mathrm{F}_{2}$ PBA: $\mathrm{R}_{1}=\mathrm{R}_{2}=\mathrm{F}, \mathrm{R}_{3}=\mathrm{B}(\mathrm{OH})_{2}$

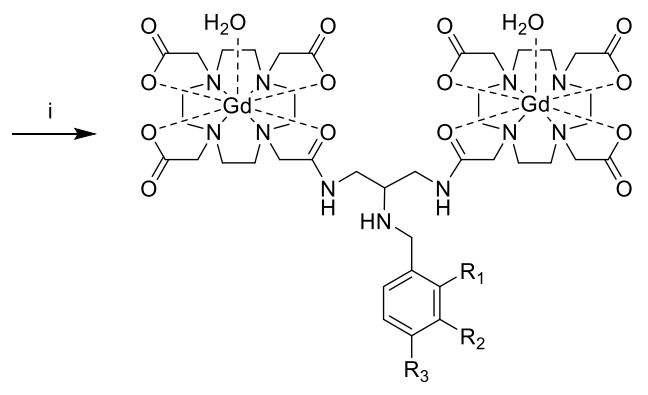

(GdDOTA-EN) ${ }_{2}$-PBA: $\mathrm{R}_{1}=\mathrm{R}_{3}=\mathrm{H}, \mathrm{R}_{2}=\mathrm{B}(\mathrm{OH})_{2}$

(GdDOTA-EN) $)_{2}-F_{2}$ PBA: $R_{1}=R_{2}=F, R_{3}=B(O H)_{2}$

Scheme 2. Synthesis of (Gd ${ }^{\mathrm{III}}$-DOTA-EN) $)_{2}$-PBA and (Gd ${ }^{\mathrm{III}}$-DOTA-EN) $)_{2}-\mathrm{F}_{2} \mathrm{PBA}$ : i) $\mathrm{GdCl}_{3} \cdot 6 \mathrm{H}_{2} \mathrm{O}, \mathrm{pH} 7,50{ }^{\circ} \mathrm{C}, 15 \mathrm{~h}$.

\subsection{Relaxometric Characterizations}

The longitudinal relaxivity value $r_{1}$ (per $1 \mathrm{mM} \mathrm{Gd}$ ) at $25^{\circ} \mathrm{C}$ and $20 \mathrm{MHz}$ of the binuclear complexes is $8.7 \mathrm{mM}^{-1} \mathrm{~s}^{-1}$ for $\left(\mathrm{Gd}^{\mathrm{III}} \text {-DOTA-EN }\right)_{2}$-PBA and $8.2 \mathrm{mM}^{-1} \mathrm{~s}^{-1}$ for $\left(\mathrm{Gd}^{\mathrm{III}}\right.$-DOTA$\mathrm{EN})_{2}-\mathrm{F}_{2} \mathrm{PBA}$, with a ca. $40 \%$ increase compared to the values measured for the mononuclear species (6.2 and $5.8 \mathrm{mM}^{-1} \mathrm{~s}^{-1}$, respectively) [9]. The relaxivity enhancement can be easily attributed to a longer value of the rotational correlation time associated with the larger molecular size, combined with the retention of the same hydration state $(q=1)$ for each metal ion. As has already been noticed for the monomeric complexes [9], the fluorinated chelate has a slightly lower relaxivity: this can probably be ascribed to a decrease in its hydrophilicity induced by the fluorine atoms on the aromatic ring that affects the hydration of the molecule and then the rotational dynamics. The obtained relaxivity values are in agreement with a $q=1$ hydration state, as confirmed by all DOTA monoamide-related studies, since the first paper about Gd ${ }^{\mathrm{III}}$-DOTAMA was reported almost 30 years ago [15].

The relaxometric characterization of each binuclear $\mathrm{Gd}^{\mathrm{III}}$ complex was carried out by recording their ${ }^{1} \mathrm{H}$ nuclear magnetic relaxation dispersion (NMRD) profiles in the frequency range 0.01 to $70 \mathrm{MHz}\left(2.34 \times 10^{-4}-1.64 \mathrm{~T}\right)$ at 25 and $37^{\circ} \mathrm{C}$ (Figure 2). The $r_{1}$ values at $37^{\circ} \mathrm{C}$ are only slightly lower than those measured at $25^{\circ} \mathrm{C}$, over the entire range of investigated proton Larmor frequencies, indicating that the water exchange rate $\left(k_{\mathrm{ex}}=1 / \tau_{\mathrm{M}}\right)$ might be slow. In Figure 3 , the NMRD profiles at $25^{\circ} \mathrm{C}$ of the two binuclear compounds are compared with the two mononuclear analogues. For the $\mathrm{Gd}^{\mathrm{III}}$ dimers a broad peak is observable at higher magnetic fields (centered at $40 \mathrm{MHz}$ ), typical of 
multimeric species and due to the effects induced by the increased molecular weight of the whole molecule on the rotational correlation time $\left(\tau_{R}\right)$ of each complex (see below).
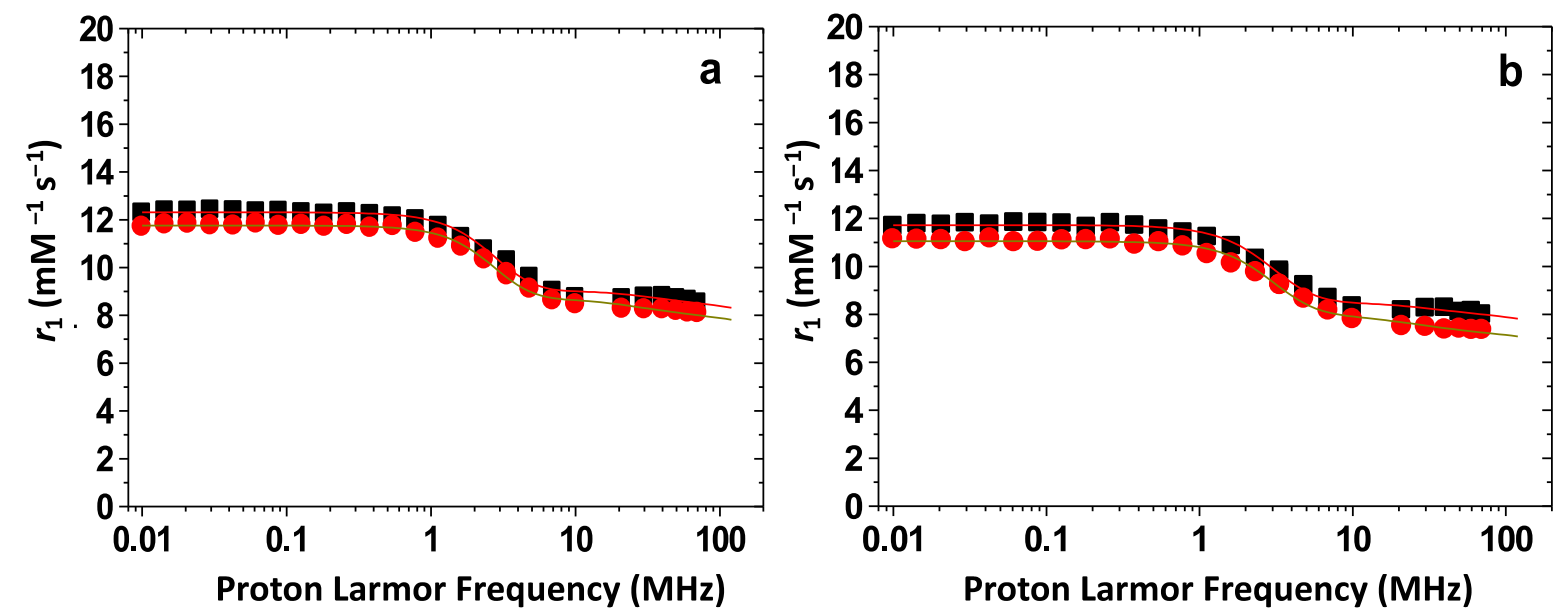

Figure 2. Comparison between the ${ }^{1} \mathrm{H}$ NMRD profiles acquired at $\mathrm{pH} 7$ and $25(\boldsymbol{\square})$ or $37^{\circ} \mathrm{C}(\bullet)$ for aqueous solutions of $\left(\mathrm{Gd}^{\mathrm{III}} \text {-DOTA-EN }\right)_{2}$-PBA (a) and (Gd ${ }^{\mathrm{III}}$-DOTA-EN $)_{2}-\mathrm{F}_{2}$ PBA (b).

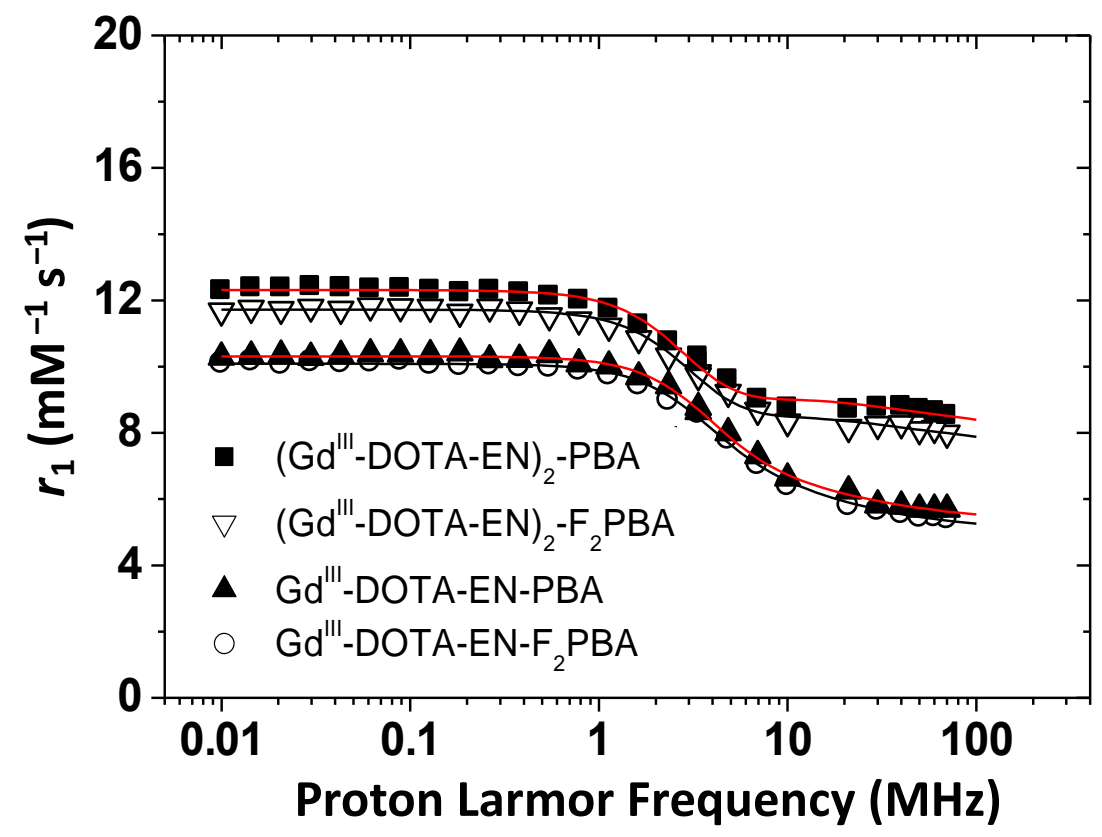

Figure 3. Comparison between the ${ }^{1} \mathrm{H}$ NMRD profiles of aqueous solutions of (GdIII-DOTA-EN) $2_{2}$ -

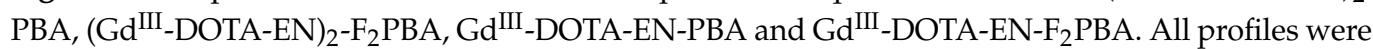
acquired at $25^{\circ} \mathrm{C}$ and $\mathrm{pH}$ 7. The solid lines represent the best-fitting results of the experimental data points.

It is noteworthy that the relaxivities of (Gd ${ }^{\mathrm{III}}$-DOTA-EN $)_{2}$-PBA and $\left(\mathrm{Gd}^{\mathrm{III}} \text {-DOTA-EN }\right)_{2}$ $\mathrm{F}_{2}$ PBA calculated per concentration of dimer are 17.4 and $16.3 \mathrm{mM}^{-1} \mathrm{~s}^{-1}$, respectively. These values imply that, in order to achieve the same MRI contrast enhancement as obtained with the corresponding monomers, it is sufficient to use a molar amount of such agents about $36 \%$ of that required for Gd ${ }^{\mathrm{III}}$-DOTA-EN-PBA or Gd ${ }^{\mathrm{III}}$-DOTA-EN-F $\mathrm{F}_{2}$ PBA.

First, a complete ${ }^{1} \mathrm{H}$ and ${ }^{17} \mathrm{O}$ NMR relaxometric study was carried out on the monomers to obtain a more accurate analysis of the water exchange dynamics of the $\mathrm{Gd}^{\mathrm{III}}$ complexes. Thus, the accurate value of the water exchange time $\tau_{\mathrm{M}}$ (Table 1) was obtained by analyzing the temperature dependence of the ${ }^{17} \mathrm{O}$ NMR transverse relaxation rate $\left(1 / \mathrm{T}_{2}\right)$ and the paramagnetic shift $(\Delta \omega)$ of the solvent water at $11.7 \mathrm{~T}$. The experimental data, reported as 
reduced transverse relaxation rates $\left(1 / \mathrm{T}_{2 \mathrm{r}}\right)$ and reduced chemical shifts $\left(\Delta \omega_{\mathrm{r}}\right)$, are shown in Figure 4 . The ${ }^{1} \mathrm{H}$ NMRD and ${ }^{17} \mathrm{O}$ NMR data were fitted simultaneously, according to the established theory of paramagnetic relaxation. Thus, while NMRD data were analyzed using the standard Solomon-Bloembergen-Morgan model for the inner-sphere relaxation mechanism [22-24] and Freed's model for the outer-sphere components [25], the temperature dependence of $1 / \mathrm{T}_{2 \mathrm{r}}$ and $\Delta \omega$ was evaluated by using the Swift-Connick equations $[26,27]$ (see details in the Supplementary Materials). Due to the number of parameters implicated in the fitting procedure, some of them were fixed to known or plausible values, namely the hydration number $(q)$, the $\mathrm{Gd}^{\mathrm{III}}-\mathrm{H}_{2} \mathrm{O}$ distance $(r)$, the distance of closest approach of the outer sphere water molecules to $\mathrm{Gd}^{\mathrm{III}}(a)$ and the relative diffusion coefficient at $25^{\circ} \mathrm{C}(D)$. The temperature dependence of $\tau_{\mathrm{V}}$ (correlation time for the modulation of the transient zero-fit splitting, ZFS) and $\tau_{\mathrm{R}}$ has been considered through their activation energies $E_{\mathrm{V}}$ (set to $1 \mathrm{~kJ} \mathrm{~mol}^{-1}$ ) and $E_{\mathrm{R}}$ (fixed to $10 \mathrm{~kJ} \mathrm{~mol}^{-1}$ ). The fit was carried out using $\tau_{\mathrm{R}}, \Delta^{2}$ (trace of the ZFS), $\tau_{\mathrm{V}}, \tau_{\mathrm{M}}$, the enthalpy of activation $\Delta H_{\mathrm{M}}$ and the scalar $\mathrm{Gd}^{-17} \mathrm{O}_{\mathrm{w}}$ coupling constant $A / \hbar$ as adjustable parameters. The best-fit parameters for Gd ${ }^{\mathrm{III}}$-DOTA-EN-PBA and Gd ${ }^{\mathrm{III}}$-DOTA-EN-F $\mathrm{F}_{2} \mathrm{PBA}$ (Table 1) show values in line with those reported for other

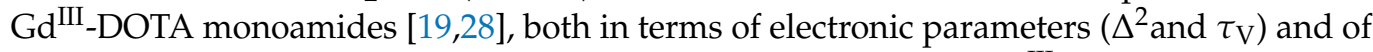
water exchange dynamics. In particular, $\tau_{\mathrm{M}}$ values of $471 \mathrm{~ns}$ for $\mathrm{Gd}^{\mathrm{III}}$-DOTA-EN-PBA and $486 \mathrm{~ns}$ for Gd $\mathrm{dII}^{\mathrm{II}}$-DOTA-EN-F $\mathrm{F}_{2} \mathrm{PBA}$ were determined, slightly lower than those reported for other Gd ${ }^{\text {III }}$-DOTA monoamides $[19,28,29]$. Finally, the shape of the $1 / \mathrm{T}_{2 \mathrm{r}}$ plot is further confirmation of a $q=1$ hydration state.

Although no variation in the water exchange parameters was expected passing from the mononuclear to the binuclear complexes, ${ }^{17} \mathrm{O}$ NMR data were acquired also for the fluorinated dimer to confirm this hypothesis (Figure 4). Therefore, the simultaneous fitting of the ${ }^{17} \mathrm{O}$ NMR and ${ }^{1} \mathrm{H}$ NMRD data for (Gd ${ }^{\mathrm{III}}$-DOTA-EN $)_{2}-\mathrm{F}_{2} \mathrm{PBA}$ and the fitting of the

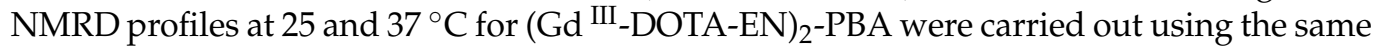
equations and procedure described above, resulting in the parameters shown in Table 1. For the binuclear complexes, the higher molecular weight $(\mathrm{MW}=$ ca $1000 \mathrm{Da})$ implies a slower rotational dynamic of the paramagnetic probes compared to the monomeric analogues $(\mathrm{MW}=\mathrm{ca} 600 \mathrm{Da})$, mirrored by the values of $\tau_{\mathrm{R}}$ (ca $100 \mathrm{ps}$ for the monomers vs. ca $200 \mathrm{ps}$ for the dimers). As mentioned above, this increase in $\tau_{R}$ is responsible for the broad peak observed in the NMRD profiles at higher magnetic field strengths. Unfortunately, the intermediate/long $\tau_{\mathrm{M}}$ values (around $0.5 \mu \mathrm{s}$ ), typical of Gd ${ }^{\mathrm{III}}$-DOTA monoamide complexes, limit the $r_{1}$ increase from mononuclear to binuclear complexes to only $40 \%$, lower than that observed when the water residence lifetime is lower than $100 \mathrm{~ns}$ (fast exchange regime) [30].

Table 1. Selected parameters obtained from the analysis of the $1 / T_{1}$ NMRD profiles at $298 \mathrm{~K}$ and the ${ }^{17} \mathrm{O}$ NMR data ${ }^{\mathrm{a}}$.

\begin{tabular}{|c|c|c|c|c|}
\hline Parameter & Gd $^{\mathrm{III}}$-DOTA-EN-PBA ${ }^{\mathrm{b}}$ & Gd $^{\mathrm{III}}$-DOTA-EN-F PBA $^{\mathrm{b}}$ & $\begin{array}{l}\left(\mathrm{Gd}^{\mathrm{III}} \text {-DOTA- }\right. \\
\text { EN })_{2} \text {-PBA }\end{array}$ & $\begin{array}{c}\left(\mathrm{Gd}^{\mathrm{III}}-\mathrm{DOTA}-\mathrm{EN}\right)_{2}- \\
\mathrm{F}_{2} \mathrm{PBA}\end{array}$ \\
\hline${ }^{20 M H z} r_{1 p}\left[\mathrm{mM}^{-1} \mathrm{~s}^{-1}\right]$ & $6.2 \pm 0.1$ & $5.8 \pm 0.1$ & $8.7 \pm 0.1$ & $8.2 \pm 0.1$ \\
\hline$\tau_{\mathrm{R}}[\mathrm{ps}]$ & $109 \pm 9$ & $102 \pm 2$ & $212 \pm 2$ & $203 \pm 2$ \\
\hline$\Delta^{2}\left[10^{19} \mathrm{~s}^{-2}\right]$ & $1.9 \pm 0.1$ & $2.1 \pm 0.1$ & $1.5 \pm 0.1$ & $1.6 \pm 0.1$ \\
\hline$\tau_{\mathrm{v}}[\mathrm{ps}]$ & $32 \pm 1$ & $29 \pm 1$ & $40 \pm 1$ & $38 \pm 1$ \\
\hline$\tau_{\mathrm{M}}[\mathrm{ns}]$ & $471 \pm 19$ & $486 \pm 27$ & $471^{\mathrm{b}}$ & $510 \pm 18$ \\
\hline$\Delta H_{\mathrm{M}}\left[\mathrm{kJ} \mathrm{mol}^{-1}\right]$ & $40 \pm 4$ & $37 \pm 4$ & - & $36 \pm 1$ \\
\hline$A / h\left[10^{6} \mathrm{rad} \mathrm{s}^{-1}\right]$ & $-3.3 \pm 0.1$ & $-3.3 \pm 0.1$ & - & $-3.3 \pm 0.1$ \\
\hline
\end{tabular}

a The following parameters were fixed to appropriate values during the fitting procedure: $q=1 ; r_{\mathrm{Gd}-\mathrm{H}}=3.0 \AA$; $a=4.0 \AA$; $D^{298}=2.24 \times 10^{-5} \mathrm{~cm}^{2} \mathrm{~s}^{-1} ; E_{\mathrm{V}}=1 \mathrm{~kJ} \mathrm{~mol}^{-1} ; E_{\mathrm{R}}=10 \mathrm{~kJ} \mathrm{~mol}^{-1} \cdot{ }^{\mathrm{b}} \tau_{\mathrm{M}}$ value determined for the mononuclear complex. 


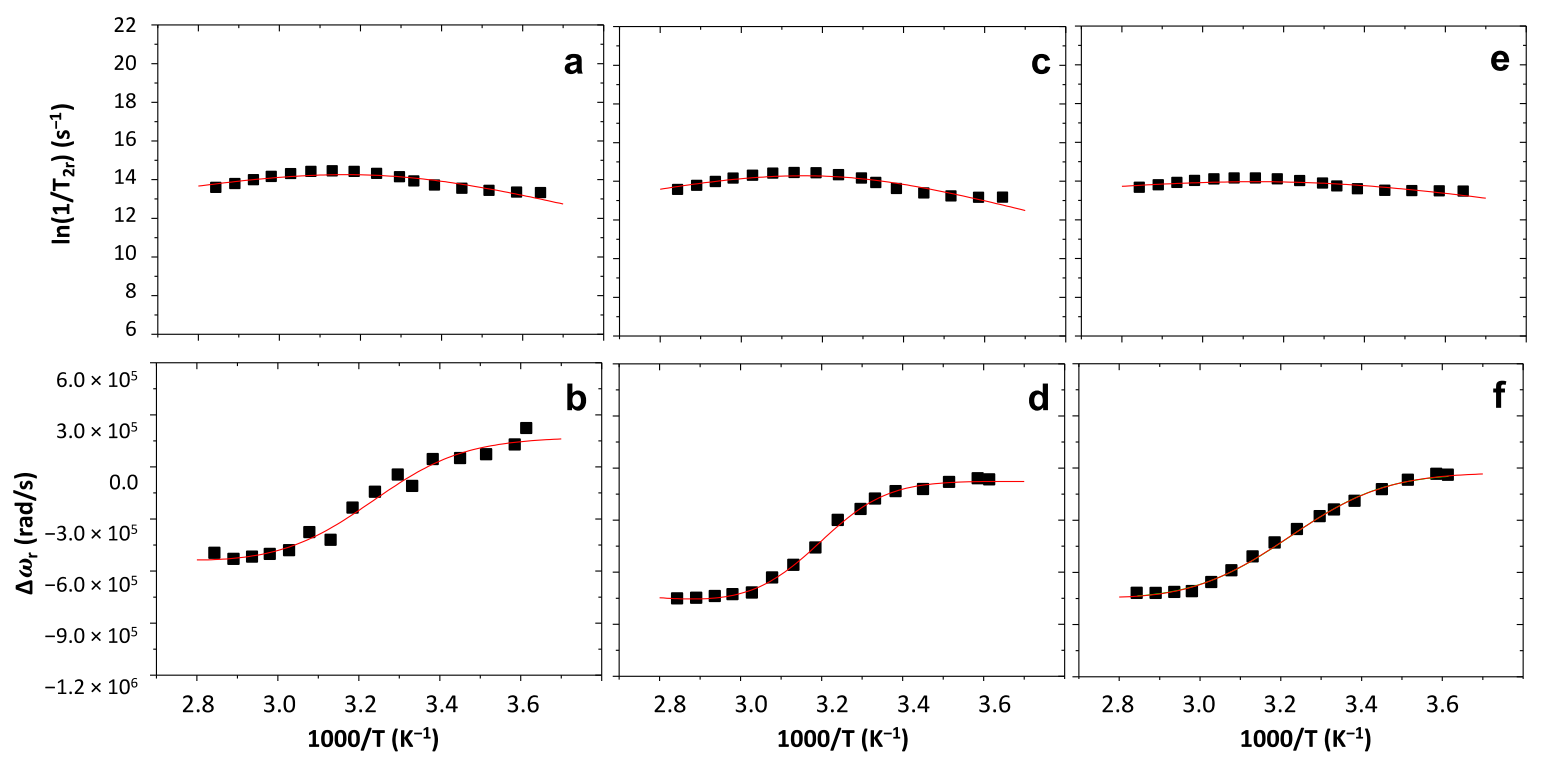

Figure 4. Reduced transverse ${ }^{17} \mathrm{O}$ relaxation rates (top) and chemical shifts (bottom) measured at $11.7 \mathrm{~T}$ and $\mathrm{pH} 7$ for $\mathrm{Gd}^{\mathrm{III}}$-DOTA-EN-PBA $(\mathbf{a}, \mathbf{b}), \mathrm{Gd}^{\mathrm{III}}$-DOTA-EN-F $\mathrm{F}_{2} \mathrm{PBA}(\mathbf{c}, \mathbf{d})$ and $\left(\mathrm{Gd}^{\mathrm{III}} \text {-DOTA-EN) }\right)_{2}-\mathrm{F}_{2} \mathrm{PBA}(\mathbf{e}, \mathbf{f})$. The solid lines represent the best-fitting results of the experimental data points.

\subsection{Determination of the Binding Efficacy}

Considering the combined improvements (i.e., the two paramagnetic ions and the higher acidity of the boronic moiety), (Gd ${ }^{\mathrm{III}}$-DOTA-EN $)_{2}-\mathrm{F}_{2}$ PBA represents the most promising dimeric MRI agent, and therefore, it was chosen for the evaluation tests on the ability of cell binding. The initial investigation was conducted on murine melanoma B16-F10 cells, in order to compare the results directly with the previous experiments on the monomeric species [9]. While the cell binding of Gd ${ }^{\mathrm{III}}$-DOTA-EN-PBA and Gd ${ }^{\mathrm{III}}$-DOTA-EN-F ${ }_{2}$ PBA was comparable, as was expected, the amount of gadolinium internalized by cells incubated in the presence of $\mathrm{Gd}$ dimer is significantly higher due to the 2:1 ratio between $\mathrm{Gd}^{\mathrm{III}}$-chelates and PBA in each molecule (Figure 5). It is possible that the presence of two chelates increases the polarity of that side of the probe, thus partially affecting its internalization by cells, and explaining why the measured Gd amount is less than twice the amount of the monomers (ca 1.5-fold).

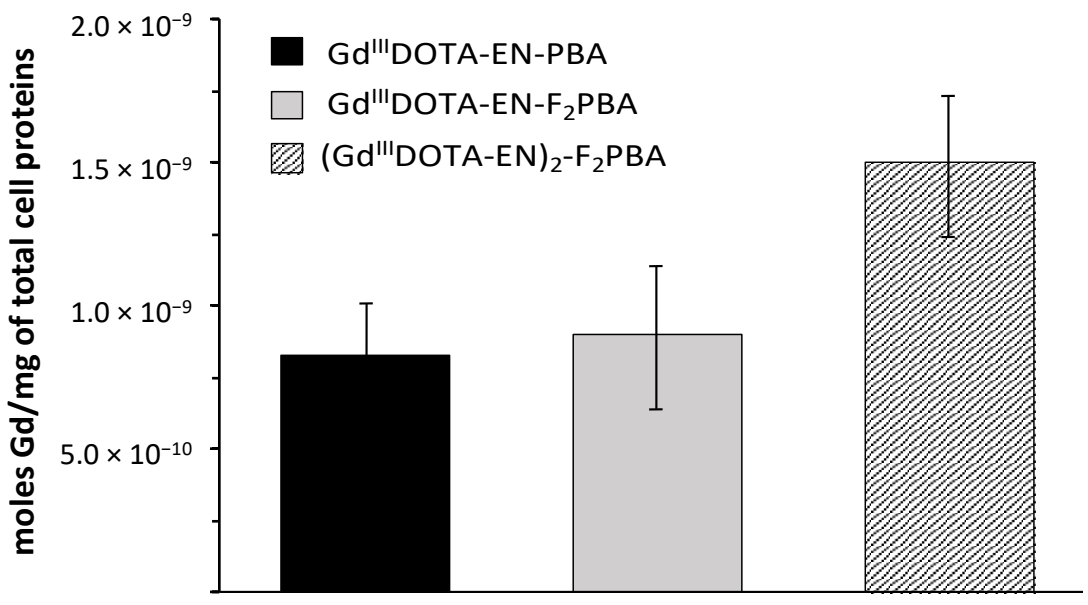

Figure 5. Evaluation of cell binding of Gd complexes upon their incubation with melanoma B16-F10 cells for $4 \mathrm{~h}$ in EBSS buffer w/o glucose at a concentration of $0.6 \mathrm{mM}$ Gd. Error bars indicate $\pm \mathrm{SD}$ and the mean values are obtained from three independent experiments. 
A study that has recently been reported in the literature highlights that mesothelioma cells express a high amount of SA on their surface [31-33]. Mesothelioma is the malignant neoplasm of the mesothelial cells and is a highly aggressive tumor lacking any significant therapies. Thus, it was decided to implement a binding test of (Gd ${ }^{\mathrm{III}}$-DOTA-EN) ${ }_{2}-\mathrm{F}_{2} \mathrm{PBA}$ with two mesothelioma cell lines (ZL34 human and AB22 murine). The results presented in Figure 6 show a high amount of cell bound fluorinated Gd dimer that, in the case of AB22, was similar to that found for the B16 melanoma. Since there is no evidence in the literature for a distinctive SA expression by mesothelioma cells of various species, the difference in binding found for AB22 and ZL34 can be explained by the intrinsic variability of SA in these tumors.

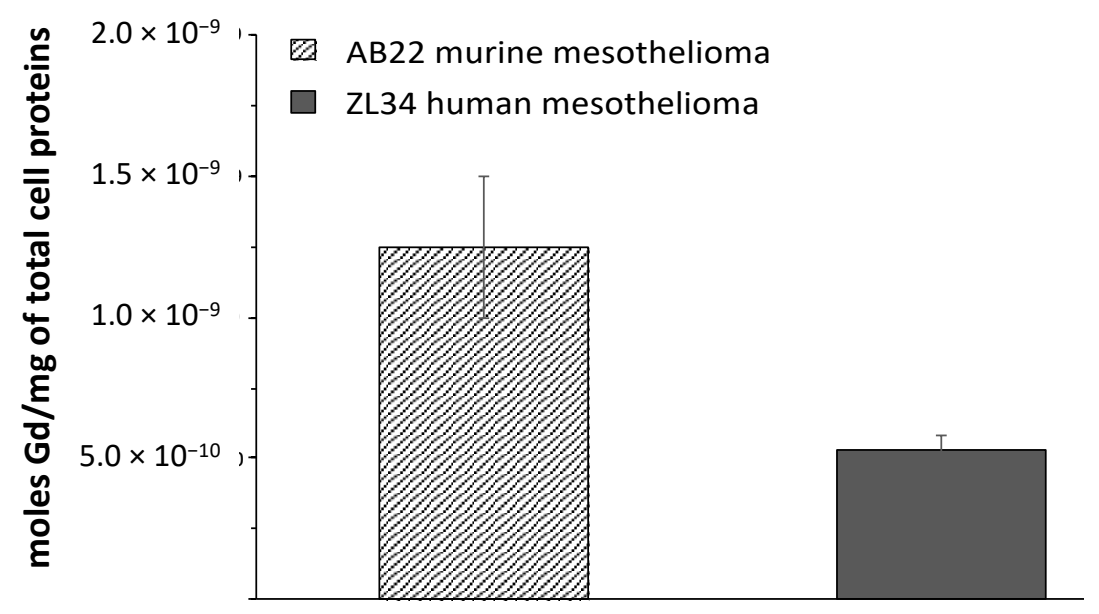

Figure 6. Evaluation of the bound (Gd $\mathrm{d}^{\mathrm{III}}$-DOTA-EN $)_{2}-\mathrm{F}_{2} \mathrm{PBA}$ complex upon incubation with AB22 (murine) and ZL34 (human) mesothelioma cells: $4 \mathrm{~h}$ incubation in EBSS buffer w/o glucose at a concentration of $0.6 \mathrm{mM} \mathrm{Gd}$. Error bars indicate $\pm \mathrm{SD}$ and the mean values are obtained from three independent experiments.

Finally, a $\mathrm{T}_{1}$-weighted MR image of AB22 and ZL34 mesothelioma cells was acquired (Figure 7a) and their corresponding $R_{1}$ was measured (Figure $7 \mathrm{~b}$ ) showing that the amount of internalized Gd is sufficient to generate a positive contrast, thus demonstrating that the probe can be used to detect mesothelioma cells.
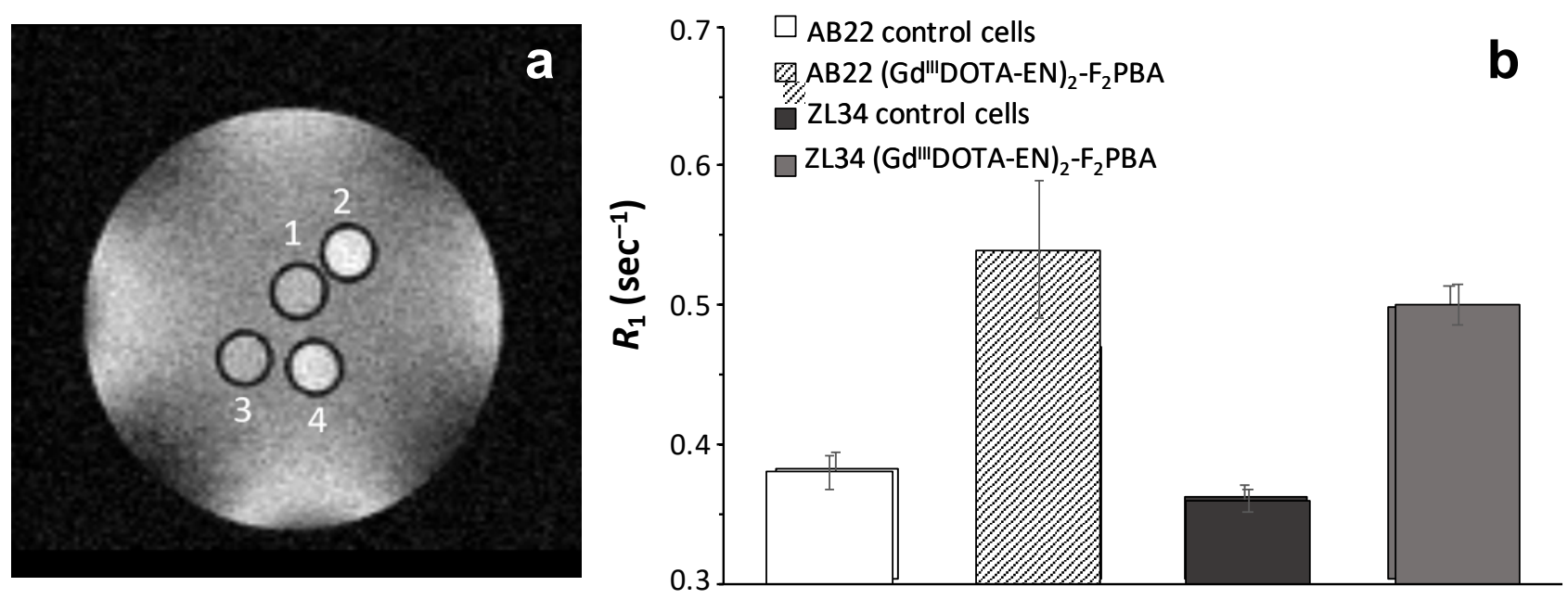

Figure 7. $\mathrm{T}_{1 \mathrm{~W}}$ image $(\mathrm{TR}=250 \mathrm{~ms}, \mathrm{TE}=3.8 \mathrm{~ms})$ of a phantom containing glass capillaries filled with $\mathrm{AB} 22$ murine mesothelioma cells (control, 1) incubated with $0.6 \mathrm{mM}\left(\mathrm{Gd}^{\mathrm{III}} \text {-DOTA-EN) }\right)_{2}-\mathrm{F}_{2} \mathrm{PBA}$ (2) and ZL34 human mesothelioma cells (control, 3) incubated with $0.6 \mathrm{mM}$ (GdIII-DOTA-EN) $)_{2}-\mathrm{F}_{2} \mathrm{PBA}(4)$ (a) and their corresponding values of longitudinal relaxivities (b). Error bars indicate $\pm S D$ and the mean values are obtained from three different slices. 


\section{Materials and Methods}

\subsection{General Remarks}

All chemicals were purchased from Sigma-Aldrich Co. (Merck, St. Louis, MO, USA), Alfa Aesar Co. (Thermo Fisher GmbH, Kandel, Germany) and Acros Organics and were used without further purification. " $\mathrm{H}_{2} \mathrm{O}$ " refers to high purity water with conductivity of $0.04 \mu \mathrm{S} \mathrm{cm}^{-1}$, obtained from a "Milli-Q" purification system. Bio-Rad AG 501-X8 resin was preliminarily washed with water and methanol. Thin-layer chromatography (TLC) was carried out on silica plates (silica gel 60 F254, Merck 5554, Darmstadt, Germany) and visualized by UV lamp ( $254 \mathrm{~nm}$ ) or stained in $\mathrm{KMnO}_{4}$, ninhydrin, bromocresol green or curcumin solution as appropriate. Preparative column chromatography was carried out using silica gel (Merck Silica Gel 60, $230 \pm 400$ mesh) pre-soaked in the starting eluent.

${ }^{1} \mathrm{H},{ }^{13} \mathrm{C},{ }^{11} \mathrm{~B}$ and ${ }^{19} \mathrm{~F}$ NMR spectra (including ${ }^{1} \mathrm{H}$-decoupled ${ }^{13} \mathrm{C}$ NMR) and homo/hetero-nuclear bidimensional maps were recorded on a Bruker Avance III spectrometer (Bruker, Milano, Italy) operating at $11.74 \mathrm{~T}$, corresponding to a protonic resonance frequency of $499.8 \mathrm{MHz}$. Samples were prepared in $5 \mathrm{~mm}$ NMR tubes by dissolving the compounds in appropriate deuterated solvents. Chemical shifts are reported in ppm relative to TMS (0 ppm for ${ }^{1} \mathrm{H}$ and ${ }^{13} \mathrm{C}$ NMR), $\mathrm{H}_{3} \mathrm{BO}_{3}\left(0 \mathrm{ppm}\right.$ for $\left.{ }^{11} \mathrm{~B} \mathrm{NMR}\right)$ and $\mathrm{CF}_{3} \mathrm{COOH}(-74.4 \mathrm{ppm}$ for ${ }^{19} \mathrm{~F}$ NMR) as internal standards. For ${ }^{11} \mathrm{~B}$ NMR experiments, a quartz tube was used. Splitting patterns are described as singlet (s), broad singlet (bs), doublet (d), double doublet $(\mathrm{dd})$, triplet $(\mathrm{t})$, multiplet $(\mathrm{m})$ or broad multiplet $(\mathrm{bm})$. Coupling constants are reported in $\mathrm{Hz}$.

ESI mass spectra were recorded on a Waters SQD 3100. Analytical HPLC-MS was carried out on a Waters modular system equipped with Waters 1525 binary pump, Waters $2487 \mathrm{UV} /$ Vis and Waters SQD 3100 (ESCI ionization mode) detectors, using an XBridge ${ }^{\mathrm{TM}}$ Phenyl $3.5 \mu \mathrm{m} 4.6 \times 150 \mathrm{~mm}$ column (Waters Corporation, Milford, MA, USA).

The water proton longitudinal relaxation rates as a function of the magnetic field strength were measured in non-deuterated aqueous solutions on a Fast Field-Cycling Stelar SmarTracer relaxometer (Stelar s.r.l., Mede (PV), Italy) over a continuum of magnetic field strengths from 0.00024 to $0.25 \mathrm{~T}$ (corresponding to $0.01-10 \mathrm{MHz}$ proton Larmor frequencies). The relaxometer operates under computer control with an absolute uncertainty in $1 / \mathrm{T}_{1}$ of $\pm 1 \%$. Additional longitudinal relaxation data in the range $20-70 \mathrm{MHz}$ were obtained on a Stelar Relaxometer connected to a Bruker WP80 NMR electromagnet adapted to variablefield measurements. The exact concentration of $\mathrm{Gd}^{\mathrm{III}}$ was determined by measurement of bulk magnetic susceptibility shifts of a $t \mathrm{BuOH}$ signal or by inductively coupled plasma mass spectrometry (ICP-MS, Element-2, Thermo-Finnigan, Rodano (MI), Italy). Sample digestion was performed with concentrated $\mathrm{HNO}_{3}(70 \%, 2 \mathrm{~mL})$ under microwave heating at $160{ }^{\circ} \mathrm{C}$ for $20 \mathrm{~min}$ (Milestone MicroSYNTH Microwave lab station equipped with an optical fiber temperature control and HPR-1000/6M six-position high-pressure reactor, Bergamo, Italy). The ${ }^{1} \mathrm{H} \mathrm{T}_{1}$ relaxation times were acquired by the standard inversion recovery method with typical $90^{\circ}$ pulse width of $3.5 \mu$ s and 16 experiments with 4 scans. The temperature was controlled with a Stelar VTC-91 airflow heater equipped with a calibrated copper constantan thermocouple (uncertainty of $\pm 0.1^{\circ} \mathrm{C}$ ).

Variable-temperature ${ }^{17} \mathrm{O}$ NMR measurements were recorded on a Bruker Avance III spectrometer (11.7 T) equipped with a $5 \mathrm{~mm}$ probe and standard temperature control unit. Aqueous solutions of the complexes $(10-20 \mathrm{mM})$ containing $2 \%$ of the ${ }^{17} \mathrm{O}$ isotope (Cambridge Isotope) were used. The observed transverse relaxation rates were calculated from the signal width at half-height.

MR images of capillaries filled with a suitable sample were acquired at $21^{\circ} \mathrm{C}, 7 \mathrm{~T}$ on a Bruker Avance 300 spectrometer equipped with a microimaging probe. $\mathrm{T}_{1 \mathrm{~W}}$ images were acquired by using a standard MSME (Multi-Slice Multi-Echo) sequence with the following parameters: $\mathrm{TR}=50 \mathrm{~ms}, \mathrm{TE}=3.3 \mathrm{~ms}, \mathrm{FOV}=1 \times 1 \mathrm{~cm}$, slice thickness $=1 \mathrm{~mm}$, matrix size $128 \times 128$. 


\subsection{Synthesis}

\subsubsection{Synthesis of Precursors}

1,3-Diamino-2-azidopropane dihydrochloride (2)

Boc-diamine 1 [20] (2.74 g, $8.70 \mathrm{mmol})$ was dissolved in $4 \mathrm{M} \mathrm{HCl}(30 \mathrm{~mL})$ and dioxane $(30 \mathrm{~mL})$ and stirred at room temperature overnight. The solvents were then evaporated and the obtained amine hydrochloride salt $(1.36 \mathrm{~g}, 83 \%)$ was used without further purification.

${ }^{1} \mathrm{H}$ NMR $\left(400 \mathrm{MHz}, 25^{\circ} \mathrm{C}, \mathrm{CD}_{3} \mathrm{OD}\right): 4.27(\mathrm{~m}, 1 \mathrm{H}, \mathrm{CH}), 3.33\left(\mathrm{dd}, J^{2}=13.5 \mathrm{~Hz}, J^{3}=\right.$ $\left.3.9 \mathrm{~Hz}, 2 \mathrm{H}, \mathrm{CHH} \underline{H}^{\prime}\right), 3.08\left(\mathrm{dd}, J^{2}=13.5 \mathrm{~Hz}, J^{3}=8.9 \mathrm{~Hz}, 2 \mathrm{H}, \mathrm{CHH}^{\prime}\right) .{ }^{13} \mathrm{C} \mathrm{NMR}(100 \mathrm{MHz}$, $\left.25^{\circ} \mathrm{C}, \mathrm{CD}_{3} \mathrm{OD}\right): 58.9\left(\mathrm{NH}-\mathrm{CH}_{2}-\mathrm{CHN}_{3}-\mathrm{CH}_{2}-\mathrm{NH}\right), 41.80\left(\mathrm{NH}-\mathrm{CH}_{2}-\mathrm{CHN}_{3}-\mathrm{CH}_{2}-\mathrm{NH}\right)$.

\section{$\operatorname{DOTA}(\mathrm{O} t-\mathrm{Bu})_{3}$}

The DO3A monoethyl ester [7] $(1.16 \mathrm{~g}, 1.93 \mathrm{mmol})$ was dissolved in $1: 1 \mathrm{H}_{2} \mathrm{O} / \mathrm{MeOH}$ $(20 \mathrm{~mL})$ and $\mathrm{LiOH}(510 \mathrm{mg}, 21.29 \mathrm{mmol})$ was added. The solution was stirred at room temperature overnight. Brine $(30 \mathrm{~mL})$ was added, and the water layer was extracted with DCM $(2 \times 20 \mathrm{~mL})$. The organic phase was dried over anhydrous $\mathrm{Na}_{2} \mathrm{SO}_{4}$, filtered and evaporated to obtain the DOTA derivative 16 as a white solid (410 $\mathrm{mg}, 37 \%$ ).

${ }^{1} \mathrm{H}$ NMR $\left(400 \mathrm{MHz}, 25{ }^{\circ} \mathrm{C}, \mathrm{CDCl}_{3}\right): 2.0-3.5\left(\mathrm{bm}\right.$, ring and acetates $\left.\mathrm{CH}_{2}\right), 1.31(\mathrm{~s}$, $\left.27 \mathrm{H}, \mathrm{CH}_{3}\right)$.

\section{(DOTA $\left.(\mathrm{Ot}-\mathrm{Bu})_{3}\right)_{2}$-1,3-diamido-2-azidopropane (3)}

Diaminoazide 2 hydrochloric salt $(100 \mathrm{mg}, 0.53 \mathrm{mmol})$ was suspended in DMF ( $5 \mathrm{~mL})$, DIPEA $(0.92 \mathrm{~mL}, 5.28 \mathrm{mmol})$ was added, and the suspension was stirred at room temperature for $30 \mathrm{~min}$. Separately, a solution of DOTA $(\mathrm{Ot}-\mathrm{Bu})_{3}(607 \mathrm{mg}, 1.06 \mathrm{mmol}), \mathrm{HOBt}$ $(143 \mathrm{mg}, 1.06 \mathrm{mmol})$ and HBTU $(402 \mathrm{mg}, 1.06 \mathrm{mmol})$ in DMF $(5 \mathrm{~mL})$ was prepared and added to the previous suspension. The mixture was stirred at room temperature overnight. The solvent was then evaporated under reduced pressure, the residue was suspended in DCM $(50 \mathrm{~mL})$ and washed with brine $(3 \times 25 \mathrm{~mL})$. The organic layer was dried over anhydrous $\mathrm{NaSO} 4$, filtered and evaporated to obtain the product as a yellowish solid (532 mg, 82\%).

${ }^{1} \mathrm{H}$ NMR $\left(400 \mathrm{MHz}, 25^{\circ} \mathrm{C}, \mathrm{CDCl}_{3}\right): 6.55(\mathrm{~m}, 2 \mathrm{H}, \mathrm{NH}), 4.11(\mathrm{~m}, 1 \mathrm{H}, \mathrm{CH}), 3.45-1.88(\mathrm{bm}$, $52 \mathrm{H}$, DOTA ring and acetates $\left.+\mathrm{CH}_{2} \mathrm{CH}\right), 1.41\left(\mathrm{~s}, 54 \mathrm{H}, \mathrm{CH}_{3}\right) .{ }^{13} \mathrm{C} \mathrm{NMR}\left(100 \mathrm{MHz}, 25^{\circ} \mathrm{C}\right.$, $\left.\mathrm{CDCl}_{3}\right): 172.8(\mathrm{COO}), 165.8(\mathrm{CONH}), 81.8\left(\mathrm{CCH}_{3}\right), 61.1(\mathrm{CH}), 55.4\left(\mathrm{CH}_{2} \mathrm{CO}\right), 52+47(\mathrm{br}$, $\mathrm{CH}_{2}$ ring), $51.8\left(\mathrm{CH}_{2} \mathrm{CH}\right), 27.7\left(\mathrm{CH}_{3}\right)$. IR: 3432, 2974, 2830, 2116, 1727, 1653, 1505.

(DOTA $\left.(\mathrm{Ot}-\mathrm{Bu})_{3}\right)_{2}$-1,3-diamido-2-aminopropane (4)

Compound 3 (450 mg, $0.37 \mathrm{mmol}$ ) was dissolved in $\mathrm{MeOH}(10 \mathrm{~mL}) ; 10 \% \mathrm{Pd} / \mathrm{C}(45 \mathrm{mg})$ was added and $\mathrm{H}_{2}$ was bubbled for $10 \mathrm{~min}$. The suspension was then stirred overnight under a $\mathrm{H}_{2}$ atmosphere. After filtration through Celite, the solvent was removed under vacuum leading to the product as a white solid ( $378 \mathrm{mg}, 85 \%)$.

${ }^{1} \mathrm{H}$ NMR $\left(400 \mathrm{MHz}, 25{ }^{\circ} \mathrm{C}, \mathrm{CDCl}_{3}\right): 6.59(\mathrm{~m}, 2 \mathrm{H}, \mathrm{NH}), 4.16\left(\mathrm{~m},{ }^{1} \mathrm{H}, \mathrm{CH}\right), 3.49-1.95(\mathrm{bm}$, $52 \mathrm{H}$, DOTA ring and acetates $\left.+\mathrm{CH}_{2} \mathrm{CH}\right), 1.72\left(\mathrm{bm}, 2 \mathrm{H}, \mathrm{NH}_{2}\right), 1.45\left(\mathrm{~s}, 54 \mathrm{H}, \mathrm{CH}_{3}\right) .{ }^{13} \mathrm{C}$ NMR $\left(100 \mathrm{MHz}, 25^{\circ} \mathrm{C}, \mathrm{CDCl}_{3}\right): 172.8(\mathrm{COO}), 165.9(\mathrm{CONH}), 81.8\left(\mathrm{CCH}_{3}\right), 55.7\left(\mathrm{CH}_{2} \mathrm{CO}\right), 54.6$ $(\mathrm{CH}), 52+48\left(\mathrm{br}, \mathrm{CH}_{2}\right.$ ring), $51.9\left(\mathrm{CH}_{2} \mathrm{CH}\right), 27.9\left(\mathrm{CH}_{3}\right)$. IR: 3500, 2976, 2829, 1722, 1653, 1538,872 .

\subsubsection{General Procedure to Bind Formylphenylboronic Acids to DEAM-PS Resin}

DEAM-PS resin $(306 \mathrm{mg}, 0.51 \mathrm{mmol})$ and a suitable PBA $(0.68 \mathrm{mmol})$ were weighed in a filter-syringe. Dry THF $(5 \mathrm{~mL})$ was added, and the reactor was shaken for $2 \mathrm{~h}$. The suspension was then filtered and washed with dry THF $(3 \times 5 \mathrm{~mL})$.

\subsubsection{Reductive Amination between 4 and PBA-DEAM-PS Resin}

PBA-DEAM-PS resin $(54 \mathrm{mg}, 0.09 \mathrm{mmol})$ was weighed in a filter-syringe and suspended in dry THF $(5 \mathrm{~mL})$. Amine $4(103 \mathrm{mg}, 0.09 \mathrm{mmol})$ was dissolved in dry THF $(2 \mathrm{~mL})$ 
and added to the reactor. The suspension was shaken for $3 \mathrm{~h}$ and it was filtered and washed with dry THF $(2 \times 5 \mathrm{~mL})$. The resulting functionalized resin was resuspended in dry THF $(5 \mathrm{~mL}), \mathrm{NaBH}_{4}(7 \mathrm{mg}, 0.18 \mathrm{mmol})$ was added, and the mixture was shaken for $4 \mathrm{~h}$. The resin was then filtered and washed with dry DMF $(3 \times 3 \mathrm{~mL})$, dry DCM $(5 \times 3 \mathrm{~mL})$ and dry THF $(3 \times 3 \mathrm{~mL})$.

\subsubsection{Cleavage and Deprotection of (DOTA-EN) $)_{2}-\mathrm{PBA}$ and (DOTA-EN) $)_{2}-\mathrm{F}_{2} \mathrm{PBA}$}

$\operatorname{DCM}(2 \mathrm{~mL})$ and TFA $(2 \mathrm{~mL})$ were added to the resin in the syringe and the suspension was shaken overnight. After filtration and washing with TFA $(3 \times 3 \mathrm{~mL})$, the combined filtrates were evaporated under reduced pressure and the products were obtained as white solids.

\section{(DOTA-EN) $)_{2}$-PBA}

Yield 32\%, $29 \mathrm{mg}$ (0.029 mmol). ${ }^{1} \mathrm{H}$ NMR (400 MHz, $\left.25{ }^{\circ} \mathrm{C}, \mathrm{D}_{2} \mathrm{O}\right): 7.83$ (bs, $\left.1 \mathrm{H}, \mathrm{CH}^{\mathrm{Ar}}\right)$, $7.52\left(\mathrm{bm}, 2 \mathrm{H}, \mathrm{CH}^{\mathrm{Ar}}\right), 6.95\left(\mathrm{bm}, 1 \mathrm{H}, \mathrm{CH}^{\mathrm{Ar}}\right), 3.7-2.8(\mathrm{bm}, 53 \mathrm{H}$, DOTA ring and acetates + $\left.\mathrm{CH}_{2} \mathrm{CHCH}_{2}\right) .{ }^{11} \mathrm{~B}$ NMR $\left(128 \mathrm{MHz}, 25{ }^{\circ} \mathrm{C}, \mathrm{D}_{2} \mathrm{O}\right): 0.019$.

\section{(DOTA-EN $)_{2}-\mathrm{F}_{2} \mathrm{PBA}$}

Yield 36\%, $33 \mathrm{mg}(0.032 \mathrm{mmol}) .{ }^{1} \mathrm{H}$ NMR $\left(400 \mathrm{MHz}, 25{ }^{\circ} \mathrm{C}, \mathrm{CDCl}_{3}\right): 7.46(\mathrm{bm}, 1 \mathrm{H}$, $\left.\mathrm{CH}^{\mathrm{Ar}}\right), 7.31\left(\mathrm{bm}, 1 \mathrm{H}, \mathrm{CH}^{\mathrm{Ar}}\right), 3.8-3.0\left(\mathrm{bm}, 53 \mathrm{H}\right.$, DOTA ring and acetates $\left.+\mathrm{CH}_{2} \mathrm{CHCH}_{2}\right)$. ${ }^{11} \mathrm{~B}$ NMR $\left(128 \mathrm{MHz}, 25{ }^{\circ} \mathrm{C}, \mathrm{D}_{2} \mathrm{O}\right): 0.019 .{ }^{19} \mathrm{~F}$ NMR $\left(376 \mathrm{MHz}, 25{ }^{\circ} \mathrm{C}, \mathrm{D}_{2} \mathrm{O}\right):-132.86(\mathrm{~d}$, $\left.J^{3}=21.2 \mathrm{~Hz}, \mathrm{CFCB}\right),-146.97\left(\mathrm{~d}, J^{3}=21.2 \mathrm{~Hz}, \mathrm{CFCCH}_{2}\right)$.

\subsubsection{General Procedure for the Preparation of $\mathrm{Gd}^{\mathrm{III}}$ complexes}

The PBA-ligand $(0.032 \mathrm{mmol})$ was dissolved in $\mathrm{H}_{2} \mathrm{O}(10 \mathrm{~mL}) . \mathrm{GdCl}_{3} \cdot 6 \mathrm{H}_{2} \mathrm{O}(17 \mathrm{mg}$, $0.045 \mathrm{mmol}$ ) was added and the mixture was stirred overnight at $\mathrm{pH} 7$ and room temperature. The $\mathrm{pH}$ was increased to $\times \approx 10$ by dropwise addition of $0.1 \mathrm{M} \mathrm{NaOH}$, and the resulting precipitate was filtered off. The $\mathrm{pH}$ of the filtrate was then returned to 7 by dropwise addition of $0.1 \mathrm{M} \mathrm{HCl}$.

\subsubsection{Cell Lines and Incubation Protocol}

Mouse melanoma (B16-F10) cell lines were purchased from the American Type Culture Corporation. Melanogenic B16-F10 cells were obtained by growing cells in standard DMEM (Lonza) medium supplemented with $3.7 \mathrm{mg} / \mathrm{mL}$ sodium bicarbonate, $4 \mathrm{mM}$ glutamine and $10 \%$ FBS $(v / v)$. Mouse mesothelioma (AB22) cell lines were obtained from Sigma-Aldrich and they were cultured in RPMI medium (Lonza, Basel, Switzerland) supplemented with $25 \mathrm{mM}$ Hepes, 10\% $(v / v)$ FBS and 2mM glutamine. Human mesothelioma (ZL34) cell line was obtained from Sigma Aldrich. The cells were cultured in DMEM-Ham's F12 (Lonza) containing $2.5 \mathrm{mM}$ glutamine and supplemented with 15\% $(v / v)$ FBS. All media contained $100 \mathrm{U} / \mathrm{mL}$ penicillin and $100 \mathrm{U} / \mathrm{mL}$ streptomycin. All the cell lines were maintained in a humidified incubator at $37^{\circ} \mathrm{C}, 5 \% \mathrm{CO}_{2}$.

For the cell binding experiments, $1.4 \times 10^{6}$ B16-F10, $4.5 \times 10^{5}$ ZL34 and $3 \times 10^{5}$ AB22 were seeded in T25 flasks. After $48 \mathrm{~h}$ for B16-F10 and ZL34 and after $24 \mathrm{~h}$ for AB22, the cells were incubated with $0.6 \mathrm{mM} \mathrm{Gd}\left(\mathrm{Gd}^{\mathrm{III}}-\mathrm{DOTA}-\mathrm{EN}\right)_{2}-\mathrm{F}_{2}$ PBA in EBSS (Earle's Balanced Salts Solution) $w / o$ glucose for $4 \mathrm{~h}$ at $37^{\circ} \mathrm{C}, 5 \% \mathrm{CO}_{2}$. All the incubations were performed at $37{ }^{\circ} \mathrm{C}, 5 \% \mathrm{CO}_{2}$. At the end of the incubation, cells were washed three times with $3 \mathrm{~mL}$ ice-cold PBS and detached with 1mM EDTA. ZL34 and AB22 cells were also transferred into glass capillaries for MRI analysis. Cells were collocated in glass capillaries inside an agar phantom and MR images were acquired using a standard $\mathrm{T}_{1}$-weighted multi slice spin echo sequence (TR (repetition time)/TE (echo time)/NEX number of excitations) = 250/3.7/6, FOV (field of view) $=1.2 \mathrm{~cm}$ ) on a Bruker Avance300 spectrometer $(7 \mathrm{~T})$ provided with a Micro 2.5 microimaging probe (Bruker BioSpin, Ettlingen, Germany). $\mathrm{T}_{1}$ relaxation times were determined using a standard Saturation Recovery Spin Echo. Finally, all cell samples were transferred in falcon tubes and sonicated at $30 \%$ of power for $30 \mathrm{~s}$ in ice. The 
Gd content of each cell sample lysate was determined by the ICP-MS technique (see below). The milligrams of proteins, proportional to the number of cells, of each cell sample lysate, were evaluated by the Bradford assay (BioRad, Hercules, CA, USA) using bovine serum albumin as a standard.

\subsubsection{Inductively Coupled Plasma Mass Spectrometry (ICP-MS)}

Gd content from cell samples was determined using inductively coupled plasma mass spectrometry (ICP-MS) (Element-2; Thermo-Finnigan, Rodano (MI), Italy). Sample digestion was performed using a high-performance Microwave Digestion System (ETHOS UP Milestone, Bergamo, Italy) after the addition of concentrated $\mathrm{HNO}_{3}(70 \%)$ to cell lysates (1:1), in a final volume of $0.4 \mathrm{~mL}$. The calibration curve was obtained using four $\mathrm{Gd}$ absorption standard solutions (Sigma-Aldrich) in the range $0.1-0.004 \mu \mathrm{g} / \mathrm{mL}$.

\section{Conclusions}

In this work, the synthesis and characterization of two novel dimeric ligands and their $\mathrm{Gd}^{\mathrm{III}}$ complexes is reported. Both (DOTA-EN) $)_{2}-\mathrm{PBA}$ and (DOTA-EN) $)_{2}-\mathrm{F}_{2} \mathrm{PBA}$ (improvement of previously reported monomeric analogous species) bear a phenylboronic acid that is meant to be exploited to target sialic acid, overexpressed by cancer cells. The solid-phase approach allowed obtaining of ligands at good yields and with very simple work-up processes. The corresponding Gd complexes were prepared according to a standard procedure and their relaxometric properties were evaluated by recording the respective NMRD profiles and by studying the temperature dependence of the ${ }^{17} \mathrm{O}$ NMR transverse relaxation rate and the paramagnetic shift of the solvent water. As expected, the higher Gd content and the bigger size (translating into a longer rotational correlation time $\left.\tau_{\mathrm{R}}\right)$ led to an average $40 \%$ improvement in the relaxivity values for $\left(\mathrm{Gd}^{\mathrm{III}} \text {-DOTA-EN }\right)_{2}$-PBA and $\left(\mathrm{Gd}^{\mathrm{III}} \text {-DOTA-EN }\right)_{2}-\mathrm{F}_{2} \mathrm{PBA}\left(8.71\right.$ and $8.16 \mathrm{mM}^{-1} \mathrm{~s}^{-1}$, respectively at $20 \mathrm{MHz}$ and $\left.25{ }^{\circ} \mathrm{C}\right)$ compared to those previously reported for the corresponding monomeric analogues (6.24 and $5.80 \mathrm{mM}^{-1} \mathrm{~s}^{-1}$, respectively). This translates, in principle, into a much lower amount (about 36\%) of dimeric Gd-chelates that is necessary to administer in order to obtain the same MRI contrast enhancement compared to the corresponding Gd monomers. By fitting the experimental data for both monomeric and dimeric species, the main relaxometric parameters were determined, including the water exchange time $\tau_{M}$ (ca. $470 \mathrm{~ns}$ ) and the rotational correlation time $\tau_{\mathrm{R}}$ that, as anticipated, is about double for the Gd dimers (ca. $200 \mathrm{ps}$ ) with respect to the monomers (ca. $100 \mathrm{ps)}$ ) due to the higher molecular weight.

Finally, the binding abilities of (Gd $\left.{ }^{\mathrm{III}}-\mathrm{DOTA}-\mathrm{EN}\right)_{2}-\mathrm{F}_{2} \mathrm{PBA}$ were investigated by comparing its internalization by melanoma and mesothelioma tumor cells: in both cases, a good amount of Gd was detected inside the cells upon incubation, which was also sufficient to produce a significant contrast effect in phantom MR images. Therefore, the reported complexes, and particularly (Gd $\left.\mathrm{GII}^{\mathrm{II}} \mathrm{DOTA}-\mathrm{EN}\right)_{2}-\mathrm{F}_{2} \mathrm{PBA}$, improved in terms of both the number of chelates (two Gd ${ }^{\mathrm{III}}$-DOTA units) and the acidity of the boronic moiety (because of the presence of two electron-withdrawing halogen atoms), were confirmed to represent a promising way to develop efficient targeting contrast agents for various diagnostic techniques such as MRI, PET and SPECT. Moreover, the presence of one boron atom on $\left(\mathrm{Gd}^{\mathrm{III}} \text {-DOTA-EN }\right)_{2}-\mathrm{F}_{2}$ PBA opens perspective for its use as a boron carrier for Boron Neutron Capture Therapy (BNCT). This alternative radiotherapy, thanks to its ability to hit the tumor with a selectivity at the cellular level, is particularly effective in the treatment of diffuse tumors such as mesothelioma [34-36].

Supplementary Materials: The following are available online, Equations used for fitting of ${ }^{1} \mathrm{H} \mathrm{NMR}$ profiles and ${ }^{17} \mathrm{O}$ NMR relaxivity data Figures S1-S3: NMR spectra, Figures S4 and S5: ESI-MS spectra, Figure S6: transmetallation data. References [21-26,37-39] are cited in the Supplementary Materials.

Author Contributions: Conceptualization, K.D.; methodology, K.D. and J.M.; synthesis and characterization, J.M.; validation, J.M. and K.D; relaxometry, L.T and J.M.; cell studies, S.G.C. and D.A.; writing, original draft preparation, J.M.; writing, review and editing, J.M., K.D, L.T. and S.G.C. 
supervision, project administration and funding acquisition K.D. All authors have read and agreed to the published version of the manuscript.

Funding: This research was funded by The Netherlands Organization for Scientific Research (NWO VENI, grant-722.012.009).

Institutional Review Board Statement: Not applicable.

Informed Consent Statement: Not applicable.

Data Availability Statement: The data are available on request from the corresponding author.

Conflicts of Interest: The authors declare no conflict of interest.

Sample Availability: Samples of the compounds are not available from the authors.

\section{References}

1. Brooks, W.L.A.; Sumerlin, B.S. Synthesis and Applications of Boronic Acid-Containing Polymers: From Materials to Medicine. Chem. Rev. 2016, 116, 1375-1397. [CrossRef]

2. Schauer, R. Achievements and challenges of sialic acid research. Glycoconj. J. 2000, 17, 485-499. [CrossRef]

3. Djanashvili, K.; Frullano, L.; Peters, J.A. Molecular Recognition of Sialic Acid End Groups by Phenylboronates. Chem. Eur. J. 2005, 11, 4010-4018. [CrossRef] [PubMed]

4. Djanashvili, K.; Koning, G.A.; Van Der Meer, A.J.; Wolterbeek, H.T.; Peters, J.A. Phenylboronate160Tb complexes for molecular recognition of glycoproteins expressed on tumor cells. Contrast Media Mol. Imaging 2007, 2, 35-41. [CrossRef] [PubMed]

5. Djanashvili, K.; Hagen, T.L.T.; Blangé, R.; Schipper, D.; Peters, J.A.; Koning, G.A. Development of a liposomal delivery system for temperature-triggered release of a tumor targeting agent, Ln(III)-DOTA-phenylboronate. Bioorg. Med. Chem. 2011, 19, 1123-1130. [CrossRef] [PubMed]

6. Frullano, L.; Rohovec, J.; Aime, S.; Maschmeyer, T.; Prata, M.I.; De Lima, J.J.P.; Geraldes, C.F.G.C.; Peters, J.A. Towards Targeted MRI: New MRI Contrast Agents for Sialic Acid Detection. Chem. Eur. J. 2004, 10, 5205-5217. [CrossRef]

7. Crich, S.G.; Alberti, D.; Szabó, I.; Aime, S.; Djanashvili, K. MRI Visualization of Melanoma Cells by Targeting Overexpressed Sialic Acid with a GdIII-dota-en-pba Imaging Reporter. Angew. Chem. Int. Ed. 2013, 52, 1161-1164. [CrossRef]

8. Tsoukalas, C.; Geninatti-Crich, S.; Gaitanis, A.; Tsotakos, T.; Paravatou-Petsotas, M.; Aime, S.; Jiménez-Juárez, R.; Anagnostopoulos, C.D.; Djanashvili, K.; Bouziotis, P. Tumor Targeting via Sialic Acid: [ ${ }^{68} \mathrm{Ga}$ ]DOTA-en-pba as a New Tool for Molecular Imaging of Cancer with PET. Mol. Imaging Biol. 2018, 20, 798-807. [CrossRef]

9. Martinelli, J.; Jiménez-Juárez, R.; Alberti, D.; Crich, S.G.; Djanashvili, K. Solid-phase synthesis and evaluation of tumour-targeting phenylboronate-based MRI contrast agents. Org. Biomol. Chem. 2020, 18, 7899-7906. [CrossRef]

10. Yan, J.; Springsteen, G.; Deeter, S.; Wang, B. The relationship among $\mathrm{pKa}$, $\mathrm{pH}$, and binding constants in the interactions between boronic acids and diols-it is not as simple as it appears. Org. Biomol. Chem. 2020, 18, 7899-7906. [CrossRef]

11. Arimori, S.; Hartley, J.H.; Bell, M.L.; Oh, C.S.; James, T.D. 'Tailored' polymers for supported syntheses using boronic acids. Tetrahedron Lett. 2000, 41, 10291-10294. [CrossRef]

12. Gravel, M.; Thompson, K.A.; Zak, M.; Bérubé, C.; Hall, D.G. Universal Solid-Phase Approach for the Immobilization, Derivatization, and Resin-to-Resin Transfer Reactions of Boronic Acids. J. Org. Chem. 2001, 67, 3-15. [CrossRef]

13. Hall, D.G.; Tailor, J.; Gravel, M. N,N-Diethanolaminomethyl Polystyrene: An Efficient Solid Support to Immobilize Boronic Acids. Angew. Chem. Int. Ed. 1999, 38, 3064-3067. [CrossRef]

14. Livramento, J.B.; Tóth, É.; Sour, A.; Borel, A.; Merbach, A.E.; Ruloff, R. High Relaxivity Confined to a Small Molecular Space: A Metallostar-Based, Potential MRI Contrast Agent. Angew. Chem. Int. Ed. 2004, 44, 1480-1484. [CrossRef]

15. Powell, D.H.; Ni Dhubhghaill, O.M.; Pubanz, D.; Helm, L.; Lebedev, Y.S.; Schlaepfer, W.; Merbach, A.E. Structural and Dynamic Parameters Obtained from ${ }^{17} \mathrm{O}$ NMR, EPR, and NMRD Studies of Monomeric and Dimeric Gd ${ }^{3+}$ Complexes of Interest in Magnetic Resonance Imaging: An Integrated and Theoretically Self-Consistent Approach1. J. Am. Chem. Soc. 1996, 118, 9333-9346. [CrossRef]

16. Tei, L.; Gugliotta, G.; Avedano, S.; Giovenzana, G.B.; Botta, M. Application of the Ugi four-component reaction to the synthesis of ditopic bifunctional chelating agents. Org. Biomol. Chem. 2009, 7, 4406-4414. [CrossRef]

17. Ranganathan, R.S.; Fernandez, M.E.; Kang, S.I.; Nunn, A.D.; Ratsep, P.C.; Pillai, K.M.R.; Zhang, X.; Tweedle, M.F. New Multimeric Magnetic Resonance Imaging Agents. Investig. Radiol. 1998, 33, 779-797. [CrossRef]

18. Fontes, A.; Karimi, S.; Helm, L.; Yulikov, M.; Ferreira, P.M.; André, J.P. Dinuclear DOTA-Based Gd ${ }^{\text {III }}$ Chelates—Revisiting a Straightforward Strategy for Relaxivity Improvement. Eur. J. Inorg. Chem. 2015, 2015, 1579-1591. [CrossRef]

19. Tei, L.; Baranyai, Z.; Gaino, L.; Forgács, A.; Vágner, A.; Botta, M. Thermodynamic stability, kinetic inertness and relaxometric properties of monoamide derivatives of lanthanide(iii) DOTA complexes. Dalton Trans. 2015, 44, 5467-5478. [CrossRef] [PubMed]

20. Odell, L.R.; Chau, N.; Mariana, A.; Graham, M.E.; Robinson, P.J.; McCluskey, A. Azido and Diazarinyl Analogues of Bis-Tyrphostin as Asymmetrical Inhibitors of Dynamin GTPase. ChemMedChem 2009, 4, 1182-1188. [CrossRef]

21. Laurent, S.; Elst, L.V.; Henoumont, C.; Muller, R.N. How to measure the transmetallation of a gadolinium complex. Contrast Media Mol. Imaging 2010, 5, 305-308. [CrossRef] [PubMed] 
22. Solomon, I. Relaxation Processes in a System of Two Spins. Phys. Rev. 1955, 99, 559-565. [CrossRef]

23. Bloembergen, N. Proton Relaxation Times in Paramagnetic Solutions. J. Chem. Phys. 1957, 27, 572-573. [CrossRef]

24. Bloembergen, N.; Morgan, L.O. Proton Relaxation Times in Paramagnetic Solutions. Effects of Electron Spin Relaxation. J. Chem. Phys. 1961, 34, 842-850. [CrossRef]

25. Freed, J.H. Dynamic effects of pair correlation functions on spin relaxation by translational diffusion in liquids. II. Finite jumps and independent T1 processes. J. Chem. Phys. 1978, 68, 4034-4037. [CrossRef]

26. Swift, T.J.; Connick, R.E. NMR-Relaxation Mechanisms of $\mathrm{O}^{17}$ in Aqueous Solutions of Paramagnetic Cations and the Lifetime of Water Molecules in the First Coordination Sphere. J. Chem. Phys. 1962, 37, 307-320, Erratum in 1964, 41, 2553. [CrossRef]

27. Merbach, A.; Helm, L.; Tóth, É. Relaxivity of Gadolinium(III) Complexes: Theory and Mechanism. In The Chemistry of Contrast Agents in Medical Magnetic Resonance Imaging; John Wiley \& Sons Ltd.: Chichester, UK, 2013; pp. 25-81. [CrossRef]

28. Tei, L.; Gugliotta, G.; Baranyai, Z.; Botta, M. A new bifunctional Gd ${ }^{\mathrm{III}}$ complex of enhanced efficacy for MR-molecular imaging applications. Dalton Trans. 2009, 9712-9714. [CrossRef]

29. Crich, G.; Cabella, C.; Barge, A.; Belfiore, S.; Ghirelli, C.; Lattuada, L.; Lanzardo, S.; Mortillaro, A.; Tei, L.; Visigalli, M.; et al. In Vitro and in Vivo Magnetic Resonance Detection of Tumor Cells by Targeting Glutamine Transporters with Gd-Based Probes. J. Med. Chem. 2006, 49, 4926-4936. [CrossRef] [PubMed]

30. Leone, L.; Ferrauto, G.; Cossi, M.; Botta, M.; Tei, L. Optimizing the Relaxivity of MRI Probes at High Magnetic Field Strengths with Binuclear GdIII Complexes. Front. Chem. 2018, 6, 158. [CrossRef]

31. Matsuura, R.; Kaji, H.; Tomioka, A.; Sato, T.; Narimatsu, H.; Moriwaki, Y.; Misawa, H.; Imai, K.; Tsuji, S. Identification of mesothelioma-specific sialylated epitope recognized with monoclonal antibody SKM9-2 in a mucin-like membrane protein HEG1. Sci. Rep. 2018, 8, 1-13. [CrossRef]

32. Tzanakakis, G.N.; Syrokou, A.; Kanakis, I.; Karamanos, N.K. Determination and distribution of N-acetyl- and Nglycolylneuraminic acids in culture media and cell-associated glycoconjugates from human malignant mesothelioma and adenocarcinoma cells. Biomed. Chromatogr. 2006, 20, 434-439. [CrossRef]

33. Tatsuta, T.; Hosono, M.; Takahashi, K.; Omoto, T.; Kariya, Y.; Sugawara, S.; Hakomori, S.; Nitta, K. Sialic acid-binding lectin (leczyme) induces apoptosis to malignant mesothelioma and exerts synergistic antitumor effects with TRAIL. Int. J. Oncol. 2014, 44, 377-384. [CrossRef]

34. Alberti, D.; Deagostino, A.; Toppino, A.; Protti, N.; Bortolussi, S.; Altieri, S.; Aime, S.; Crich, S.G. An innovative therapeutic approach for malignant mesothelioma treatment based on the use of Gd/boron multimodal probes for MRI guided BNCT. J. Control. Release 2018, 280, 31-38. [CrossRef] [PubMed]

35. Alberti, D.; Michelotti, A.; Lanfranco, A.; Protti, N.; Altieri, S.; DeAgostino, A.; Crich, S.G. In vitro and in vivo BNCT investigations using a carborane containing sulfonamide targeting CAIX epitopes on malignant pleural mesothelioma and breast cancer cells. Sci. Rep. 2020, 10, 1-13. [CrossRef] [PubMed]

36. Sasai, M.; Nakamura, H.; Sougawa, N.; Sakurai, Y.; Suzuki, M.; Lee, C.M. Novel Hyaluronan Formulation Enhances the Efficacy of Boron Neutron Capture Therapy for Murine Mesothelioma. Anticancer Res. 2016, 36, 907. [PubMed]

37. Powell, D.H.; Merbach, A.E.; González, G.; Brucher, E.; Micskei, K.; Ottaviani, M.F.; Köhler, K.; Von Zelewsky, A.; Grinberg, O.Y.; Lebedev, Y.S. Magnetic field-dependent electronic relaxation of $\mathrm{Gd}^{3+}$ in aqueous solutions of the complexes $\left[\mathrm{Gd}\left(\mathrm{H}_{2} \mathrm{O}\right)_{8}\right]^{3+}$, [Gd(propane-1,3-diamine- $N, N, N^{\prime}, N^{\prime}$-tetraacetate $\left.)\left(\mathrm{H}_{2} \mathrm{O}\right)_{2}\right]^{-}$, and [Gd( $N, N^{\prime}$-bis[( $N$-methylcarbamoyl)methyl]-3-azapentane-1,5diamine-3,N,N'-triacetate) $\left.\left(\mathrm{H}_{2} \mathrm{O}\right)\right]$ of interest in magnetic-resonance imaging. Helv. Chim. Acta 1993, 76, $2129-2146$.

38. Helm, L. Relaxivity in paramagnetic systems: Theory and mechanism. Prog. Nucl. Magn. Reson. Spectrosc. 2006, $49,45-64$. [CrossRef]

39. Costa, J.; Ruloff, R.; Burai, L.; Helm, L.; Merbach, A.E. Rigid $\mathrm{M}^{\mathrm{II}} \mathrm{L}_{2} \mathrm{Gd}_{2}{ }^{\mathrm{III}}(\mathrm{M}=\mathrm{Fe}, \mathrm{Ru})$ complexes of a terpyridine-based heteroditopic chelate: A class of candidates for MRI contrast agents. J. Am. Chem. Soc. 2005, 127, 5147-5157. [CrossRef] [PubMed] 